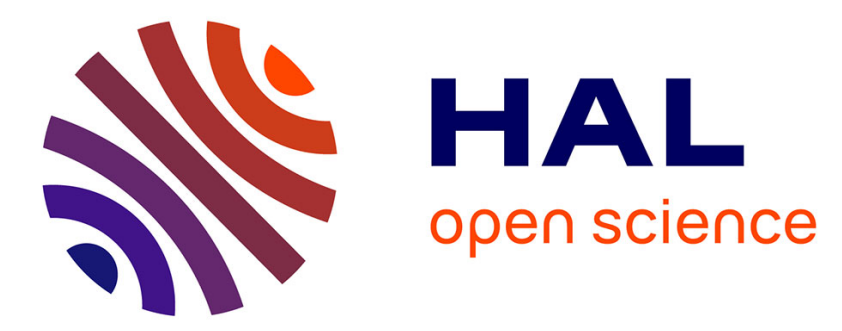

\title{
The Use of the Internet in Science Teaching: A Longitudinal Study of Developments in use by Student Teachers in England
}

Pete Sorensen, John Twidle, Ann Childs, Janet Godwin

\section{- To cite this version:}

Pete Sorensen, John Twidle, Ann Childs, Janet Godwin. The Use of the Internet in Science Teaching: A Longitudinal Study of Developments in use by Student Teachers in England. International Journal of Science Education, 2007, 29 (13), pp.1605-1627. 10.1080/09500690601137676 . hal-00513333

\section{HAL Id: hal-00513333 \\ https://hal.science/hal-00513333}

Submitted on 1 Sep 2010

HAL is a multi-disciplinary open access archive for the deposit and dissemination of scientific research documents, whether they are published or not. The documents may come from teaching and research institutions in France or abroad, or from public or private research centers.
L'archive ouverte pluridisciplinaire HAL, est destinée au dépôt et à la diffusion de documents scientifiques de niveau recherche, publiés ou non, émanant des établissements d'enseignement et de recherche français ou étrangers, des laboratoires publics ou privés. 


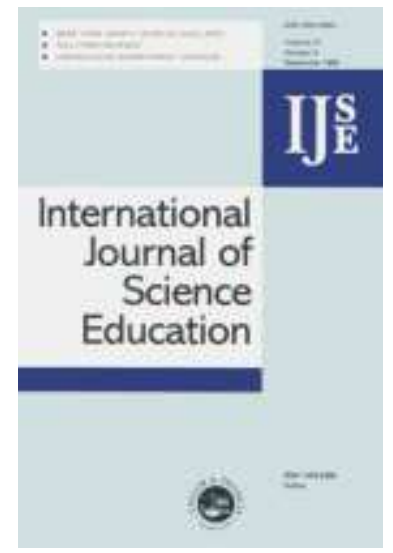

The Use of the Internet in Science Teaching: A Longitudinal Study of Developments in use by Student Teachers in England

\begin{tabular}{|r|l|}
\hline Journal: & International Journal of Science Education \\
\hline Manuscript ID: & TSED-2006-0120.R1 \\
\hline Manuscript Type: & Special Issue Research Paper \\
\hline Keywords: & science education, information technology, teacher knowledge \\
\hline Keywords (user): & science teacher education, ICT, secondary \\
\hline \multicolumn{2}{|l}{} \\
\hline
\end{tabular}

\section{ऽ ScholaroNE" \\ Manuscript Central}


RESEARCH REPORT

\section{The Use of the Internet in Science Teaching: A Longitudinal Study}

\section{of Developments in use by Student Teachers in England}

This paper reports on a longitudinal study of developments in use of the Internet by science student teachers on Post Graduate Certificate of Education (PGCE) courses in five higher education institution - schools partnerships in England. These are one year, full time, teacher training courses for graduate scientists. The aim of the research was to examine changes in attitudes to, and use of, the Internet to support science teaching and the perceived challenges and barriers to practice in schools, against a background of high national expectations reflected in the qualification standards of the teacher education courses_(TTA, 2002). The research has involved nearly 600 student teachers, representing between $7 \%$ and $8 \%$ of those training on PGCE science courses in England, and has employed mixed methods, with questionnaires serving as the main basis for analysing trends, and focus groups and case studies used to gain deeper insight to the particular issues identified. The process has been an iterative one, with the outcomes of each year's research being used to inform further research and course developments in the institutions involved. The findings indicate that attitudes and confidence in use of the Internet have improved over the period, with evidence of increased application directly in the classroom. However, in addition to some of the generic technological issues that may hinder developments in the use of ICT in schools, there are continuing concerns relating to limited pedagogical guidance and availability of good role models. The implications of this for developments in science teacher education programmes are discussed. 


\section{Introduction}

Governments across the world have been keen to promote the use of Information and Communication Technology (ICT) in schools and the UK has been no exception (DfES, 2002). This emphasis on ICT is underpinned by an increasing body of research indicating that teaching and learning is promoted in schools that make good use of ICT resources and such research makes strong reference to the affordances of the Internet (BECTa, 2001, 2002; DfES, 2003a; Osborne \& Hennessy 2003). Set against this, some have

Deleted: Becta questioned the benefits of the use of computers in schools and concerns have been raised about ineffective use of the Internet (e.g. Brabazon, 2002, 2005; Cordes \& Miller, 2000). There has also been a continuing frustration at the apparent slow uptake of ICT in some schools, and science has been no exception in this regard (Poole, 2000).

As in many countries, the government in England has sought to embed its expectations concerning the use of ICT within their training frameworks (TTA, 2002) and through the financing of organisations and websites designed to support practising teachers (e.g. NGfL, 2002). Alongside this, a lot of money has been allocated to the development of ICT facilities in schools. In terms of the Internet, virtually every secondary school now has access and by $200386.5 \%$ of computers were already connected to the Internet, an average of about 150 per school at the start of this research project, more than five times those available in 1999 (DfES, 2003b). This survey also reported that $82 \%$ of teachers expressed confidence in their ability to use ICT, compared to $70 \%$ just two years earlier. However, more detailed research findings have continued to show that many teachers still lack confidence in their use of ICT (DfES, 2001, Selinger \& Austin, 2003) and such evidence mirrors that found by investigators in other parts of the world (e.g. Kirshner \& Selinger, 2003). It is also interesting to note that the DfES (2003b) survey found that only $57 \%$ of teachers were making regular use of ICT in their subject teaching, a figure that had remained fairly static for two years. The survey did not probe 
into the nature of such use in depth, but the numbers making regular use directly in the classroom were likely to be significantly lower than $57 \%$, as were those who access the Internet on a regular basis. This assertion of limited use of the Internet in current practice in schools is supported by data from the recent, large scale Impact2 study (Harrison et al., 2003) which notes that at both Key Stage 3 (11 to 14 year olds) and Key Stage 4 (14 to 16 year olds) the most common answer to how often pupils used the Internet in lessons was 'never' and the combined figures for 'hardly ever' and 'never' were $84 \%$ and $79 \%$ at each key stage respectively. Regular use was only reported by an average of about $4 \%$ of pupils (Harrison et al., 2002).

The challenges facing the practising teacher in respect of integrating new technology into their teaching are well documented (e.g. Norum, Grabinger \& Duffield, 1999; White, 2000). These challenges mean that even those willing to embrace change often face pressures of time and lack of resources or training which mitigate against development. Set against such challenges, it is no surprise to find that research shows that, far from leading to major shifts in pedagogical practices, rather that the technology itself is moulded to current practice (Goodson \& Mangan, 1995). Watson (2001) has argued strongly for a shift to considering 'pedagogy before technology' and many researchers have stressed the need to rethink the role of the teacher in engaging with new technologies (e.g. Scanlon, 1997; White, 2000; John \& Sutherland, 2004). This moulding to current practice can probably be further understood if initiatives appear to be led by the technology and comes from the kind of top down decision making prevalent in some countries, of which England is an example. In such circumstances teachers are unlikely to embrace the possibility of changing pedagogies, especially if there is little tradition of discussing pedagogy, something which is, again, a characteristic of many schools in England. Simon's (1980) paper on this issue probably remains as relevant today as it was then.

Alongside this, the models adopted in curriculum development terms have often also been of a transmissive, top down nature, which would seem to be a contradiction in terms to some of the ways the instruments themselves are supposed to transform teaching. This was true of many of the New Opportunity Funding 
(NOF) training models (NOF, 2002), which used $£ 230$ million of National Lottery money over the period 2000 - 2003 in seeking to develop the ICT skills of practising teachers and the ineffectiveness of some of the models has been reflected in many evaluations and surveys of impact. However, those trainers who adopted a more collaborative, constructivist approach, requiring work with whole departments and building on current departmental practice, such as that provided by the science consortium, were much more successful (Rogers \& Finlayson, 2003). Overall, it is clear that the lessons learned from NOF training showed that for practising teachers the challenges for change are great, so it is all the more so for beginning teachers facing a multitude of other challenges and fears.

As teacher educators it is our responsibility to prepare our student teachers to enter the educational landscape described above and respond to the challenges faced. Thus, in terms of the Internet, we must ensure that they have an understanding of the debates concerning its use as a tool for teaching and learning and how such debates might inform possible use, the technical skills required and any pedagogical issues specific to the Internet, all against a background of limited understanding of the teaching and learning issues associated with the Internet and limited use within schools but strong pressure from government agencies and inspection regimes to develop 'competence' in order to meet defined standards. This is certainly a challenge and in response to concerns about the preparation and competence of our own student teachers, a group of science tutors in five partnerships of schools and Higher Education Institutions (HEIs) in England set up a research project to investigate the current situation in their partnerships.

The five partnerships work with students on one year, full time, secondary level, Post Graduate Certificate of Education (PGCE) courses. Students are from a range of science degree backgrounds, have chemistry, physics and biology specialisms, and are taught on a cohort basis in a mixture of separate and mixed subject groupings. In line with national expectations, they spend 60 days at the HEI and 120 days in school undertaking teaching practice. In England there are close partnerships between the HEIs and the schools, with 
a mentor in the school practicum for each student teacher. The mentor is jointly responsible, with the tutor from the HEI, for organising, supporting and assessing the student teachers' teaching practice. However, even if the tutors themselves are clear about all the issues, affordances and transformations to practice possible through the use of the new technology, and our personal view based on our own experience is that they are not, the large proportion of time spent in schools presents further challenges in terms of the tutors' role. An additional consideration is that the time given to the mentors to fulfil their role is itself small and, as described above, these mentors may often be the very teachers who are themselves struggling to come to grips with the new technology, yet who are expected to take a leading role in supporting the student teachers.

The initial work formed part of a project funded through ESCalate (Twidle, Sorensen, Childs, Godwin \& Dussart, 2006) and led on to further work funded through the British Educational Communications and Technology Agency BECTa (Twidle, Childs, Dussart, Godwin and Sorensen, 2005) and the continuing Deleted: Twidle et al., 2002

Deleted: et al longitudinal study reported in this paper. The broad aims of this work have been to:

- examine the starting competences and attitudes to the use of the Internet of student science teachers on one year PGCE courses;

Deleted:

- identify barriers to progress in the use of the Internet with pupils in the classroom;

- develop models of support within the PGCE courses which seek to overcome the barriers identified;

- develop and share models of pedagogical practice;

- analyse and evaluate changes in practice over time.

\section{Methods and Sample}

This longitudinal investigation has involved five HEIs and their partnership schools over a four year period and has employed mixed methods in seeking to both determine trends and examine practice in depth. The institutions include long established universities, newer universities and a university college moving to 
university status. All are regarded as being strong training institutions. Each cohort has included between 128 and 166 student teachers, representing between $7 \%$ and $8 \%$ of all science students training in a particular year. The breakdown of students according to specialisms (biology, chemistry or physics) was similar to the national statistics for each year of the research.

A range of strategies, involving focus groups, questionnaires, and case studies of practice were employed to examine particular questions developed to meet the main aims of the project (see below). These research methods were further refined in the light of each phase of the investigation. The research was set up on the basis of faculty tutors researching into student teachers' attitudes and use of the Internet but further developments and linked projects during years three and four led to mentors being more directly involved in the investigation. Table 1 shows the numbers involved in different phases of the research.

[Insert Table 1 here]

The longitudinal study was framed by an initial investigation during year one of the study, examining attitudes and use of the Internet. This involved focus groups of university tutors and student teachers and case studies of practice to examine key questions to be considered in the research. These centred on the following areas:

1. What was the current use of the Internet by students?

2. What levels of confidence did students have in their use of the Internet?

3. What was the current use of the Internet by other science teachers?

4. What constraints existed that prevented students from using the Internet?

5. What perceptions did students have of the potential for the Internet as a tool to support their teaching?

6. What perceptions did students have of their success in using the Internet and how did they analyse such success? 
1

5

7. Were there any identifiable groups of students with needs that could be collectively addressed?

It was in seeking to answer these questions that a broad range of research tools were developed.

Initially pilot questionnaires were developed and focused discussions conducted to check on interpretation of questions and inform modification of the pilot questionnaire. The final questionnaire was then completed by student teachers close to the end of their main teaching practice and case studies involving structured interviews and observations of lessons with a sample of students from each of the partnerships carried out. The outcomes of this investigation have been reported in detail elsewhere (Twidle et al 2006).

The questionnaire was chosen as a key tool for the research as it allowed the researchers to gain a broad perspective across the institutions and gather such data year on year for comparison purposes. At the same time, the advantages of working with cohorts of student teachers meant that some of the problems associated with questionnaires, such as distortions arising through low returns, could be minimised through linking completion to times when the students were together in university sessions. Thus the questionnaire would provide data reflective of the entire cohort, some of a quantitative nature, which could be analysed year on year to see if there was evidence of changes in attitudes and practice. However, as well as ethical considerations, there are risks associated with using questionnaires with captive audiences, where there might be expectations of judgements being made in relation to particular responses, especially if the researchers are involved in working with the subjects of research in other ways. This is particularly acute where power relationships are involved, as with tutors and students on PGCE courses, and responses could relate to the work of the researchers involved. Efforts were made to minimise these effects by emphasising that completion was voluntary; making all responses anonymous and separating the collection process in the HEIs from any course assessment processes during the same period, something that was helped by doing the questionnaire near the end of the course so that no data was analysed before the students had left, further supporting 
anonymity. Alongside this, the purposes of the research were made explicit to the students in course development terms, so that they could see the value of this for both themselves and future cohorts.

The questionnaire itself contained two types of closed questions. First, descriptive ones, which allowed Deleted: ly students to be categorised according to age, gender, subject specialism and home access to the Internet. These were categories identified by the original focus groups to examine question 7 from the research list. Secondly, questions using a four point Likert rating scale, designed to explore the type and frequency of their current use of the Internet, both at home and at school (question 1); their confidence in using the Internet (question 2); their perceptions of use by others in the science department at the school (question 3); their views on the potential of the Internet as a tool for learning (question 5); their views on their success in using the Internet to find information and as part of lessons (question 6). In examining the frequency of use, a scale of: 'never', 'rarely', 'sometimes', 'frequently' was employed. In examining success, the scale used was: 'no success', 'rarely successful', 'sometimes successful', 'usually successful'. Whilst for effectiveness the categories were: 'not effective', 'rarely effective', 'sometimes effective' and 'usually effective'. No further guidance was given for these categories. The Likert scale was employed as it is a relatively straightforward way to gain more precise information than that from dichotomous questions and tends to work well in allowing comparisons across sample sizes of above a hundred, where the impact arising due to different interpretations of terms such as 'frequent' by cases in the sample become less problematic (Oppenheim, 1992).

In addition to the closed questions, further, more open, questions were used to look at: constraints to their use of the Internet, whether at home or at school; areas for development that would increase their use of the Internet (question 4 of the research) and details of their perceived successful use of the Internet (probing further into question 6). In setting these open questions, a similar, grounded basis to analysing the data was planned, in line with the approach for the structured interviews. 
The structured interviews and observations of practice with a small sample of 11 students in year one brought triangulation procedures to the research and allowed for the questions to be probed in more depth. Here, nonprobability sampling was employed, with all but one of the students chosen through purpose. This was that they had made use of the Internet in a number of lessons and had viewed at least some of that use as successful. The reason for choosing this sampling technique was that it allowed an examination of ideas of 'success' and 'good practice' and of the barriers that existed in more detail. In addition to probing the original questions there was a new or extended emphasis on:

- the type of school the student attended for their main teaching practice, including the computer facilities and Internet access, and its impact on their views and practice;

- student teachers' perceptions of practice in the placement science department;

- students' use of the Internet in teaching, including types of use, groups, successes/failures, challenges, barriers to use related to specific topics and lessons;

- students' confidence at the end of the course, their future plans and needs.

The structured interviews themselves explored the same areas as those in the questionnaires, in relation to specific lessons. The lesson observations were conducted using an observation proforma. The details of this aspect of the research are part of other research, reported elsewhere (Twidle et al., 2006). However, they are referenced here as the outcomes served to inform the longitudinal study. Their use allowed for an insight to be gained into the detail of procedural issues; instructions and support; organisation of groups; layout of room; nature of task; interactions taking place and ends of lesson. It also brought a pupil perspective to the analysis, particularly in relation to success criteria.

In years two and three, the questionnaire was repeated across institutions and further research conducted using case studies of the practice of two or three students in each institution $(n=12)$ (Childs, Twidle, Sorensen \& 
Godwin, in press). This was again a non-probability sample, but this time volunteers were selected to reflect a range of specialisms, ages and prior experience of using the Internet. The foci of the case studies were informed by the previous research outcomes as part of an iterative process. As part of the case studies, structured interviews were conducted with the students, with a similar focus to those conducted in year one, but also including an overall perspective of practice. This allowed for further comparative data to be gathered and_inform the longitudinal study. These processes were repeated again in year four in four of the HEIs, while further research was conducted to examine the way tutors, mentors and student teachers work together in developing use of the Internet. The outcomes of this work are not reported here, but interviews with student teachers were again conducted as part of the longitudinal study and triangulation processes.

The analysis of outcomes from each year of the study was used to inform practice in the participating institutions in the following year. Thus $s_{2}$ alongside the research into attitudes and practice have been course developments designed to support students in developing their practice. This has included modifications to sessions at the HEIs, the development of web-based materials to support students and discussion of research outcomes with mentors and students. Thus, in examining the data there have been opportunities to look at the impact of such changes on later cohorts. However, the research was not designed in such a way as to attempt to examine any causal relationships.

Overall, then, the questionnaires were used to gather data that allowed changes in attitudes and practices to be discerned, whilst the structured interviews, observations and case studies allowed for some deeper insight into practice. The latter have also been used to illustrate trends identified through the questionnaires.

\section{Data analysis, results and trends}

The discussion of the results of the data analysis is structured around the responses to the questionnaires that were conducted over four years. The case study data are used to illuminate the questionnaire data and support
Deleted:

Deleted: funded in part by Escalate and involving more case studies, 
further discussion. Thus the starting points are presented in relation to the first year's data and any trends then referenced and discussed.

The return rates on the questionnaires were, as expected, high. In the first year this was $82 \%$, and in each of the following three years, in excess of $90 \%$, with an average of $93 \%$ of those completing the courses. The lower figure in year one was due to one institution allowing the questionnaires to be returned by post. Thus there is high confidence that the data is a fair reflection of the views of the overall cohorts of those completing their PGCE courses, within the limitations of the tool itself and questions posed. The main findings from year one are considered first before moving on to the longitudinal study.

At the start of year one it was felt that question 6 from the earlier list, concerning whether there were any identifiable subgroups within each cohort with particular needs in relation to supporting their use of the Internet, was an important one. If this were the case, it would allow such groups to be targeted in successive years and subsequent data gathered in relation to impact on practice. However, analysis of the year one data showed no differences in beliefs, attitudes and practice on the basis of age, gender, subject specialism or home access to the computer This analysis, which sought to determine differences in attitudes, practice and beliefs Deleted: (Twidle et al., 2002) of the different cohorts, was repeated using the data in successive years and it has remained the case that no differences have been detected. This has meant that there has been no attempt to develop particular targeted provision for specific groups. It has been beyond the scope of the research to determine whether there are other specific categorisations that affect the way student teachers start their engagement with Internet use in teaching.

In terms of headline points that arose from the year one data it was clear that:

- whilst most student teachers felt that they had basic competence in Internet use, there was a need for some training in terms of operational skills for a few;

- the potential for the Internet to motivate pupils and promote learning was seen by most students; 
- use of the Internet in many HEI partnership schools was fairly limited and there were few, if any, good role models in the schools;

- the student teachers felt they needed more support in terms of the pedagogy of Internet use and felt relatively ill prepared in this regard.

Alongside the expected concerns about the hardware, software, access, reliability and support systems in the schools, three significant barriers were identified:

1. a lack of knowledge of suitable sites and huge range of sites available of varying quality, making searching very time-consuming;

2. a lack of knowledge of what contributed to an effective web-based lesson;

3. a lack of sufficient role models within partnership schools who could provide student teachers with examples of and advice upon how to deliver suitable lessons.

Deleted: (Twidle et al., 2002) not have had an impact on the trends reported below. This issue is returned to in the final section.

In order to examine trends from the closed questions in the questionnaire data across the four years, simple quantitative methods were employed. The Mann-Whitney, U, test was used to make year on year comparisons and Kruskal Wallis to make comparisons across the four years, where data were available for all four years, and across three years where this wasn't possible, due to some modifications of the questionnaire after year one. The modifications were part of the iterative process and related to the collection of further data felt useful and, in one case, the changing of the way a question was asked to remove possible ambiguity. The statistical tests used were chosen in view of the non-parametric basis of the statistics gathered in the questionnaires. The Kruskal Wallis test allows for conclusions to be drawn about the overall trends, with Mann-Whitney, U, allowing for particular changes to be considered between particular years, where this might be considered 
1 significant. Summary data tables are presented as comparisons across either four years or three years according to the data available, with accompanying Kruskal Wallis statistics tables. Tables 2 and 3 refer to items and significances over four years, Tables 4 and 5 to those over three years. The codes $1-4$ at the top of the statistics tables are left general, with their meaning indicated in the sections below discussing the particular trends. For questions used over three years with a Yes/No answer (see Table 4), codings of 0/1 or $1 / 2$ are used and the value of these is made clear in the analysis. Where detail of numbers and percentages helps illustrate particular points, these are included within the discussion. The question numbers jn the tables are those from the questionnaires and are listed in Appendix 1.

[Insert Tables 2, 3, 4 and 5 here]

[Insert Appendix 1 at the end]

As a general point arising from the data, it is worth noting that the Mann Whitney analysis showed that there were significant changes for some items from years one to two and two to three but no significant changes discernible for any of the areas between years three and four. As the ones that do change can be explored through the Kruskal Wallis tests, the Mann Whitney tables are omitted. In presenting percentages in the discussion, comparisons are made between the baseline data of year one and the average of years three and four where this is considered helpful in illustrating the changes. In all cases where this is done, the Kruskal Wallis test indicates significance across the four year samples.

The outcomes which follow are presented according to the questions which framed the research and the categories from the questionnaire. In each case the questionnaire data and analysis is used first and the case studies are then used to exemplify the points made.

Perceptions of confidence in searching the Internet
Deleted: listed

Deleted: discussion relate to those given in the tables. 
Two questions were asked here, with responses limited to 'novice' 'competent' or 'expert' categorisations. Question 1a examined competence in using search engines and $1 \mathrm{~b}$ examined competence in using search phrases within a search engine. In terms of the search engines, there has been a growth in those considering themselves expert over the four years $(\mathrm{p}<0.01)$, leveling off in year four. Less than $1 \%$ of student teachers have declared themselves novice in the latter three years. The move towards viewing themselves as expert in using search terms was less pronounced but there was also evidence of some progress here $(\mathrm{p}<0.05)$.

\section{Access at home}

This relates to question 2 and there has been no significant change here, with between $80 \%$ and $90 \%$ having access at home. In terms of course expectations, it meant that the remaining student teachers needed to rely on the university or school for access. In support of this, access for student teachers at school is a requirement of partnership. As indicated earlier, lack of access at home does not seem to have been a significant factor in student teachers' use in teaching and learning. Interviews with those in this position showed that they had generally found a way round this via friends, family or close proximity to HEI facilities.

\section{Use of the Internet away from school}

Here frequency of use of the Internet for four particular purposes was explored, using a response spread of 'never', 'rarely', 'sometimes', and 'frequently'. Question 3a looked generally at use for lesson preparation and a marked trend was evident $(\mathrm{p}<0.001)$, with year on year increases in use from $42 \%$ making frequent use in year one to $68 \%$ in year four and only $6 \%$ reporting little or no use by year four. In terms of preparation of self-study materials for pupils (including web quests and worksheets that take pupils to one or more sites), question $3 \mathrm{~b}$, a similar trend was evident $(\mathrm{p}<0.001)$, with a rise from $13 \%$ making frequent use to an average of $30 \%$ in years three and four, though $30 \%$ continued to make little or no use in this respect in year four. The 
pattern of use for the preparation of interactive study materials for pupils (requiring them to respond or input data and receive a response, e.g. a quiz) was also clear $(\mathrm{p}<0.001 \%)$ but here starting numbers for frequent users were only $8 \%$, moving to an average of just over double this in the latter two years. In this case an average of just over $41 \%$ continued to make little or no use for this purpose. The final question examined use for pure interest and there was also an increase here $(\mathrm{p}<0.01)$, this time from a stronger starting point with just under three quarters of the cohort now frequent users for their own interest and leisure purposes.

\section{Use of the Internet at school}

The same four questions relating to home use were also used in relation to use at school outside of the classroom (questions $4 a-4 d)$. Here significant trends $(p<0.001)$ were seen in all cases, in the same direction of increasing use as for that seen at home. Unsurprisingly, the figures for school use were lower in all cases. However, from a base of $44 \%$ making little or no use of the Internet at school for lesson preparation, this had reduced to an average of only $13 \%$ in years three and four. Again, less of the students were using the Internet for producing study materials for pupils.

\section{Student teachers' use of the Internet in lessons}

This area was probed over three years only. Question 7a simply sought to determine whether student teachers had ever used the Internet in a lesson on teaching practice. Here the number who had had remained static at around $90 \%$. Whilst this is high, expectations on the course are that all make some use in the classroom, so either a stubborn $10 \%$ of schools are not providing the opportunity or some students are avoiding use. In addition the case studies indicated that even for those who had made some use of the Internet, this was often fairly limited. Whilst this sample was not representative, overall the nature of its selection each year, not least 
the voluntary basis of such processes, meant it was likely to be skewed towards those who had tended to make more use of the Internet rather than less. Thus it seems likely that student teachers' use of the Internet in the classroom remained fairly light.

Questions 7b1-7b3 sought to probe the type of use, respectively as a demonstration tool, for individual pupil research or for extraction of information from specific sites. Here the use for research and finding information had started fairly high, with both above $70 \%$ and there had been little change. However, a significant growth in the use as a demonstration tool $(\mathrm{p}<0.01)$ could be seen, from $36 \%$ in year two to $57 \%$ in year four. A further category of open question was also included here, allowing student teachers to mention other uses, and there was evidence of a broader range starting to appear, supported by further mentions of interactive sites, games, models, simulations and access to live events and news items during interviews and within the case studies.

Question 7c examined views of successful use in lessons, with a scale of 'no success', 'rarely successful', 'sometimes successful' and 'usually successful'. Here responses have remained similar, with about $95 \%$ reporting 'sometimes' or 'usually successful'. However, within this figure those who only report 'sometimes' remain at about a third. The questionnaires did not attempt to determine the basis of the success criteria applied by the student teachers. However, this has been a significant part of the work of the case studies and is referenced in the later discussion.

Finding Information

URL: http://mc.manuscriptcentral.com/tsed Email: editor_ijse@hotmail.co.uk 
Question 10 examined success rates in searching the Internet and the responses here have remained high and positive, with approaching 90\% saying they were 'usually successful' and no one reporting little or no success.

\section{Potential of the Internet as a tool for teaching}

This was probed in question 12 and the figures have remained fairly constant. This shows that only a very small number of students remain unconvinced of its potential, but on the other hand only about half see it as 'usually effective'. This issue is returned to in the discussion.

\section{Science teachers' use of the Internet in partnership schools}

Two questions were asked in relation to student teachers' perceptions of frequency of use by teachers in the science department. Question 5 concerned use with classes and question 6, only used for the latter three years, use in planning. It was recognised that these were likely to be difficult things for the student teachers to judge but overall patterns could give some insight into departmental practice. The analysis showed that perceptions of use of the Internet by teachers in the classroom had remained little changed over the four years, with some evidence of a slight increase in use but not of statistical significance. Thus close to half were seen as making little or no use of the Internet with their classes and only an average of about $10 \%$ seen as frequent users. However the data over the last three years concerning lesson preparation showed that there was an increase $(\mathrm{p}<0.001)$ but the teachers who were frequent users at school were only about $13 \%$, less than a third of the figure for the students. This is hardly surprising given that preparation time for teachers is at a premium. The

data were probed in more depth in the structured interviews, where it was apparent that the student teachers Deleted: was were often taking a lead within a department. Again, this is an issue discussed later. 
Factors preventing students from using the Internet in schools

This was an open question and broad categories were assigned to responses using a grounded approach in the analysis. The analysis is presented in Table 6 .

\section{[Insert Table 6 here]}

The data from the structured interviews was used to help interpret answers where it was difficult to classify responses. Thus a response of 'lack of access' could mean the computers with Internet access did_not exist or there were problems booking them or they were a long way from normal teaching rooms or, indeed, a mixture of such interpretations. In this case, interviews showed that booking rooms was the biggest of these issues but clearly this would_not be a problem if there were more resources. Thus the first two categories of the table overlap considerably.

Deleted:

Deleted:

Deleted:

Deleted: below

Deleted: $\mathrm{s}$

Deleted: as

\section{Areas for development that would increase the use of the Internet for teaching}

This was also probed by an open question. Here the number of students who commented each year was similar, about two thirds, and the distribution of comments was also similar. Thus, as indicated in the outcomes of the framing research, about half the worries concerned resources, rooming, reliability and speed of access, while the other concerns were for improved knowledge of sites and more guidance and expertise to support. In terms of the latter concerns, this seems to indicate that the initial attempts by course tutors to 
improve preparation have had little impact. Again, possible reasons for this are discussed later. However, there is one piece of information from the questionnaire which is encouraging in this respect. One of the questions used in the questionnaire probed which search engines the students used most often. In years one and two, only six different search engines were mentioned, growing to nine by year three and even then, of the nine, only three were mentioned by more than 10 of the cohort, with $95 \%$ citing Google. However, in year four, the number of sites mentioned had increased by a factor of eight, to 72, many of which were science specific sites and mentioned several times and only $45 \%$ mentioned Google. Several also wrote "too many to mention', something not seen before. Thus awareness of directly useful science sites seems to have increased.

\section{Discussion and Conclusions}

The main focus of this paper is a consideration of the trends determined in the beliefs, attitudes and use of the Internet by student teachers. The research has been conducted against a background of a strong government focus on the use of ICT in general and use of the Internet in particular, with strong expectations imposed on the HEI partnerships. There are clearly positive trends identified through the quantitative data and these are discussed below in the light of the baseline data from the first year of the research. However, the more detailed probes into practice show that use remains fairly limited and there is_not a clear understanding of what constitutes good use of the Internet. The issues arising from this evidence are developed in the latter sections of the discussion.

It is clear that most student teachers from these institutions regard themselves as competent in their own ability to use the Internet as they finish their courses. The research did not attempt to gather baseline data in terms of prior perceptions of competence but analysis of ICT audits at the start of the course from one of the participating institutions showed that over $96 \%$ viewed themselves as at least competent in using search engines and phrases. This is reflected in the fact that beginners' sessions on the Internet were abandoned in 
that institution even before this particular research started (2001). Researchers in the other participating HEIs

report similar findings. In addition, the data show that there have been developments in such confidence over

the four year period. At the same time, student teachers use the Internet more, both in and away from school, are aware of and access a broader range of sites and make more use of the Internet with pupils beyond basic research tasks.

Set against this, the student teachers continue to face considerable obstacles in seeking to make use of the Internet and there is relatively little evidence of more practice being seen in partnerships schools. There are, of course, stark exceptions to such generalisation and one of the challenges for the HEI partnerships is how to develop systems which share good practice, both within and across partnerships. This is the more so as studies such as Impact2 indicate 'a significant statistical relationship between ICT and achievement...in science at Key Stage 3, and...at Key Stage 4' (Harrison et al., 2002, p6) and argue, therefore, for 'action to reduce the digital divide' (p7).

The student teachers' continued concerns over resources may seem a little surprising as the DfES (2003a) statistics show a big rise in provision over the period and the students often showed awareness about such new resources during interviews. However, there are a number of possible explanations for this. First, the HEIs were putting more stress on Internet use, thus possibly raising expectations of use in schools. Secondly, as schools themselves developed expertise, this might mean more teachers seeking to access computer rooms. Thirdly, Ofsted inspectors, advisory teachers and the national science strategy guidance all increased expectations of teachers, thus pressurising resources. Fourthly, as technology improves, so do our expectations of it. Today's 'slow server' may be ten or a hundred times faster than yesterday's or, indeed, capable of doing things that yesterday's could_not do at all. However, the reference points of the students involved do not necessarily relate back to the older technology and instead tend to be based on the current potential, thus things could always be better from this perspective. 
In seeking to understand some of the reasons for the limited progress seen ${ }_{2}$ it is instructive to examine some of the underlying issues further. In the following discussion such issues are considered in relation to: the government agenda concerning modernisation of schools and improving standards; the emphasis on technology rather than pedagogy; cultural perspectives; and continuous professional development issues. Finally the impact of such issues on the nature of initial teacher education is considered in seeking to determine a way forward.

In terms of the modernising agenda the figures presented at the start of this paper show that in England, as in other countries, there is a clear commitment to developing the use of ICT in schools. However, several authors have commented on the lack of integrated thought given to the application of ICT in schools and a lack of appropriate assessment tools to accompany such changes (Leach \& Moon, 2000; Hennessy, Ruthven $\&$ Brindley, 2005). The arguments made here lend further weight to earlier points concerning centralised approaches with a strong emphasis on the technology and much less on the learning. The impact of this in terms of the practice both seen by our students and then, in many cases replicated in lessons analysed in the case studies, was clear to see. Thus the talk is often of 'doing an Internet lesson' first and any thoughts about learning issues a poor second: the theory - practical divide revisited as an 'on the computers' - 'other lessons' split. This was manifested in the science objectives tending to get lost in lessons and a sense of some students still simply 'doing an Internet lesson' because it was an expectation rather than seeing it as a tool to draw on in supporting learning. This was particularly likely to be the case where departments were more limited in their practice. Thus the same challenge exists for practising teachers as for beginning teachers, in line with the comments from several authors on the degree of challenge provided by the implementation of new technologies in general (e.g. Selwyn, 1999; McCormick \& Scrimshaw, 2001).

In terms of cultural perspectives, the introductory section shows that change is difficult to achieve and most Deleted: $\mathbb{I}$ likely to occur when there are collaborative processes in place and practitioners willing to actively engage 
with the pedagogic issues. Thus, Lave and Wenger's (1991) arguments for situating learning in forms of 'social participation' and actually engaging in the process, which they term 'legitimate peripheral participation', can be applied to the situation of student teachers in the practicum. However, the research trend indicated in the results has been one where we have not seen an increase in use by practising teachers and thus the active engagement and social participation has not often been enacted. Indeed, in-depth discussions concerning the role of the Internet in supporting teaching and learning, involving mentors and student teachers, have not been common in the cases studies underpinning this research. Thus while the importance of the mentors in supporting the student teachers is stressed as key in much of the literature (e.g. Galanouli \& McNair, 2001; Cuckle \& Clarke, 2002) it appears from this research that many of the teachers in the collaborating schools are not in a position to provide such support in relation to the Internet.

This brings us to the whole issue of what good professional development might look like. There is much research in this field, including a recent review in relation to science by Bishop \& Denley (2005). The outcomes of this review are in accord with other, more generic reviews and the lessons learned have been summarised by work in Queensland (QSITE, 2004) in examining the efficacy of different professional development models. They argue that professional development:

1. must support teachers' lifelong learning through reflection (practice to theory) - personal growth.

2. must improve teaching practice through action (theory to practice) - context.

3. should foster active membership and collegiate relationships within professional communities community.

4. professional development should consider the need for timeliness and reflection over time for practising teachers - time.

What are the issues, then, for initial teacher education in the light of the four issues outlined above? One critique of current practices in many countries is the separation of theory and practice inherent in the structure 
1

2

3

of the courses. Thus there is a sense in which the disjuncture between HEIs and schools serves to mitigate against collaborative approaches, even in England where partnership arrangements are closer than many other countries. In line with this, some of the students, in considering the barriers to Internet in both the questionnaire and case study research, felt that sessions conducted at the university seemed far removed from the realities of the school in which they were teaching. At the same time there is not a shared language of pedagogy ${ }_{2}$ involving the student teachers, tutors and cooperating teachers, in which to consider possible changes arising from new technologies. It is also the case that initial teacher education has tended to be seen as separate from continuing professional development as it takes place in schools. Thus attempts to develop use at the HEI level may not fit with perceived needs within the schools, even if the HEI expectations are in line with national expectations. This analysis of the issues indicates that the four areas cited as important for $\underline{\text { successful professional development are, in many cases, in need of considerable development. How can }}$ student teachers reflect ("practice to theory) if there is a lack of understanding of the theory? How can they improve through action ('theory to practice') if there is limited context in which to carry this out and lack of a 'community' in which such action can be based?

The issue of the lack of clarity in relation to good pedagogical practice is one that has been raised in both the questionnaire research and the more detailed case studies. It is clear from this research that there is relatively little innovative practice seen in the HEI-school partnerships involved in these partnerships. This is clearly not a problem that is unique to these schools as the literature review at the start has indicated. However, there have been some projects reported internationally which have sought to address such problems. Thus Linn (2003), reviewing trends across twenty five years of developments in the use of technology, noted that whilst many students continue to be educated on programmes that make very limited use of the potential of the technologies, there is more innovative practice in some settings. In her own work designing Knowledge Integration Environments (KEIs) she has stressed the need to develop a 'partnership enquiry process' to such 
development, drawing 'successful pedagogical principles', and involving 'natural scientists, science education researchers, technologists and classroom teachers (Linn, 2000 p781) and this approach is at the core of further work in the development of the Web-based Inquiry Science Environment (WISE) (Linn, Clark and Slotta, 2003). The approach in the HEIs involved in this research has been to seek to develop understandings of the pedagogical issues relating to use of the Internet and foster collaborative practices between HEIs and schools, drawing on the work with KEIs (Childs et al, in press). The evidence from the trends seen in our research shows that this may have had some impact without really being in any sense transformative in changing pedagogical practice. Moreover, it has been noted that the changes from year three to four have not been significant and the reason for this may well be that much more is needed in terms of fostering collaborative approaches within the context and community of schools.

The conclusion that much needs to be done for pedagogical practice to change reflects the evidence from the review of literature in the introduction and this is reflected on an international scale. Thus, in examining public schools in Cyprus, Vrasidac and McIsaac (2001) argue for reform of teacher education programmes to support technology integration but Angeli (2005) found that implementing instructional design models specifically intended to change practice requires a sustained commitment, concluding that 'students will be able to effectively develop the competencies needed to teach with technology only when teacher educators systematically infuse technology throughout the teacher education curriculum' (p395).

Further support for the collaborative arguments outlined in this discussion can be found in the work of Clift, Mullen, Levin and Larson (2001). In their research on the integration of technology into teacher education programmes they argue for the importance of support for all teacher education participants, including faculty, in seeking to change practice. At the same time they also note that the potential for beginning teachers to act as change agents is often cited but rarely planned. They therefore argue for 'more deliberate programme designs in which occasions for mutual learning and the sharing of expertise are emphasized' (op. cit. p48).
Deleted: $\mathbb{q}$

Deleted: and $\mathrm{t}$ Deleted: the Deleted: an Formatted: Underline Deleted: However,
Deleted: This is part of the reason for furthering work to bring schools and HEIs closer together in their partnerships to help overcome barriers to learning. 
1
Such structures are ones that might serve to overcome some of the difficulties faced by the student teachers in this research. Thus the next phase of our work is to develop collaborative use of the Internet involving student teachers, mentors and tutors, with a view to producing support materials and disseminating good practice across partnerships and between HEIs.

\section{Acknowledgements}

The first stage of the research was supported by an ESCalate grant (Education Subject Centres: Advancing Learning and Teaching in Education). ESCalate is a Centre for staff working in Higher Education and Further Education who teach Education and Continuing Education. It is involved in a wide range of staff development activities related to promoting high quality learning and teaching in Higher Education. For further details see: http://www.escalate.ac.uk

Work in the middle stages was supported by a grant from BECTa, the British Educational Communications and Technology Agency, who provide those who work in the schools sector with a range of advice and support services for learning, teaching and managing with ICT. BECTa is the UK Government's partner in the strategic development and delivery of its information and communications technology (ICT) and e-learning strategy for the schools and the learning and skills sectors. For further details see: http://www.becta.org.uk/index.cfm

\section{Bibliography}

Angeli, C. (2005). Transforming a teacher education method course through technology: effects on preservice teachers' technology competency. Computers and Education 45(4), 383-398
Deleted: s

Deleted: 
BECTa (2001). The Secondary School of the Future: A preliminary report to the DfEE. Retrieved November $4^{\text {th }} 2004$ from http://www.becta.org.uk/research/research.cfm?section=1\&id=341.

BECTa (2002). Connecting Schools, Networking People: ICT Practice, Planning and Procurement for the National Grid for Learning. Coventry: Becta.

Bishop, K. and Denley, P. (2005). Creating a culture for continuous professional development for science teachers - a view from below. In Pinto, R. and Couso, D. (Eds.) Proceedings of the fifth International ESERA Conference on Contributions of Research to Enhancing Students' Interest in Learning Science. (pp. 773-777). Barcelona, Spain.

Brabazon, T. (2002). Digital Hemlock. Sydney: University of New South Wales Press.

Brabazon, T. (2005). Graduating to information literacy. IDATER on-line conference Retrieved November $8^{\text {th }} \quad 2005 \quad$ from http://www.lboro.ac.uk/departments/cd/research/groups/ed/elearning/Lead\%20papers/BrabazonPDF.p df.

Childs, A., Twidle, J., Sorensen, P. and Godwin, J. (in press). Trainee teachers' use of the Internet opportunities and challenges for initial teacher education. Research in Science and Technological Education, 25(1).

Clift, R. T., Mullen, L. Levin, J. and Larson, A. (2001). Technologies in contexts: implications for teacher education. Teaching and Teacher Education 17(2001), 33-50

Cordes, C. and Miller, E. (2000). Fool's Gold: A critical look at computers in childhood. Retrieved November $4^{\text {th }} 2004$ from http://www.allianceforchildhood.net/projects/computers/computers_reports.htm .

Cuckle, P. \& Clarke, S. (2002). Mentoring student-teachers in schools: views and practices and access to ICT. Computer Assisted Learning, 18, 330-340.
Deleted: Becta

Deleted: Becta
Formatted: Left, Indent: Before: 0 pt, First line: $0 \mathrm{pt}$, Line spacing: single
Formatted: Normal, Left, Indent: Before: 0 pt, First line: 0 pt

Deleted: $\mathbb{I}$

Formatted: Heading 1, Left, Indent: Before: 0 pt, First line: 0 pt, Line spacing: single
39

40 
1

DfES (2001). ImpaCT2: Emerging findings from the evaluation of the impact of information and communications technologies on pupil attainment. Norwich: HMSO.

DfES (2002). Transforming the Way We Learn: A Vision for the Future of ICT in Schools. Norwich: HMSO.

DfES (2003a). ICT and attainment: A review of the research literature. Retrieved November $4^{\text {th }} 2004$ from http://www.becta.org.uk/page_documents/research/ict_attainment_summary.pdf.

DfES (2003b). Survey of Information and Communications Technology in Schools 2003. Retrieved December $5^{\text {th }} 2005$ from: http://www.dfes.gov.uk/rsgateway/DB/SBU/b000421/index.shtml.

Galanouli, D. and McNair, V. (2001). Students' perceptions of ICT-related support in teaching placements. Journal of Computer Assisted Learning, 17, 396-408.

Goodson, I. F. and Mangan, J. M. (1995). Subject cultures and the introduction of classroom computers. British Educational Research Journal. 21(5), 613-628.

Harrison, C., Fisher, T., Haw, K., Lewin, C. Lunzer, E., A. Mavers, D. et al. (2002). Impact 2: Evaluation of the Impact of Information and Communications Technology on Pupil Attainment: Report presented to Becta/DfES, February 2002.

Harrison, C., Comber, C., Fisher, T., Haw, K., Lewin, C. Lunzer, E. et al. (2003). Impact 2: The Impact of Information and Communications Technology on Pupil learning and Attainment. Norwich: DfES

Hennessy, S., Ruthven, K. and Brindley, S. (2005). Teacher perspectives on integrating ICT into subject teaching: Commitment, constraints, caution and change. Journal of Curriculum Studies, 37(2), 155192.

John, P.D. \& Sutherland, R. (2004). Teaching and Learning with ICT: new technology, new pedagogy? Education, Communication and Information, 4(1), 101-107.

Kirschner, P. and Selinger, M. (2003). The state of affairs of teacher education with respect to information and communications technology. Technology, Pedagogy and Education, 12(1), 5 - 17. 
Lave, J. and Wenger, E. (1991). Situated Learning : Legitimate Peripheral Participation. Cambridge:

Cambridge University Press.

Leach and Moon (2000). Pedagogy, information and communications technology and teachers' professional knowledge. The Curriculum Journal, 11(3), 385 - 404.

Linn, M. C. (2000). Designing the Knowledge Integration Environment. .International Journal of Science Education, 22(8), 781-796

Linn, M. C. (2003). Technology and science education: starting points, research programs, and trends. International Journal of Science Education, 25(6), 727-758

Linn, M. C., Clarke, D. and Slotta, J. D. (2003). WISE design for knowledge integration. Science Education, $\underline{87(4), 517-538}$

McCormick, R and Scrimshaw, P. (2001) ICT, Knowledge and Pedagogy. Education, Communication and Information, 1 (1) Available at http://www.open.ac.uk/eci

NGfL (2002) Virtual Teachers Centre (Accessed on-line at: http://vtc.ngfl.gov.uk/ on $4^{\text {th }}$ November 2004).

New Opportunities Fund (NOF) (2002) (Accessed on-line at: http://www.learningschools.net/NOF.htm July $\underline{2005)}$

Norum, K.E., Grabinger, R.S. \& Duffield, J.A. (1999). Healing the Universe is an Inside Job: Teachers' Views on Integrating Technology. Journal of Technology and Teacher Education, 7(3), 187-203.

Oppenheim, A.N. (1992). Questionnaire Design, Interviewing and Attitude Measurement. London: Pinter Publishers.

Osborne, J and Hennessy, S. (2003). Literature review in science education and the role of ICT: Promise, problems and future directions. Retrieved November $4^{\text {th }} 2004$ from http://www.nestafuturelab.org/research/reviews/se01.htm . 
Poole, P. (2000). Information and Communications Technology in Science Education. In Sears, J. and Sorensen, P. (eds.) Issues in Science Teaching (pp. 209-218). London: Routledge Falmer.

QSITE (2004). Towards a Model of Effective Professional Development in ICT for Teachers Retrieved January $10^{\text {th }} 2006$ from www.qsite.edu.ac/uploads/documents/store/doc_1_5/_execsummary.pdf.

Rogers, L. and Finlayson, H. (2003). Does ICT in science really work in the classroom? Part 1, The individual teacher experience. School Science Review 84(309), 105-111.

Scanlon, E. (1997). Learning Science Online. Studies in Science Education.30, 57-92

Selinger, M. and Austin, R. (2003). A comparison of the influence of government policy on information and communications technology for teacher training in England and Northern Ireland Technology. Pedagogy and Education 12(1), 19 - 38.

Selwyn, (1999). Why the computer is not dominating schools: a failure of policy or a failure of practice? Cambridge Journal of Education. 29(1), 77 - 91

Simon, S. (1980). Why no pedagogy in England? In Leach, J. and Moon B (1999) (eds) Learners and Pedagogy (pp. 34-45). London: OUP and Paul Chapman

TTA (2002). Qualifying to Teach: Professional Standards for Qualified Teacher Status and Requirements for Initial Teacher Training. London: Teacher Training Agency

Twidle, J., Childs, A., Dussart, M., Godwin, J. \& Sorensen, P. (2005). Exploring the elements that make an effective web-based science lesson. British Education Communications and Technology Authority (Becta) on behalf of the Department for Education and Skills. Retrieved January $10^{\text {th }} 2006$ from: http://www.becta.org.uk/research/research.cfm?section=1\&id=4821

Twidle, J., Sorensen, P., Childs, A., Godwin, J. \& Dussart, M. (2006). Issues, challenges and needs of student science teachers in using the Internet as a tool for teaching. Technology, Pedagogy and Education, 15(2), $207-221$.
Deleted: .II

Twidle, J., Childs, A., Dussart, M., Godwin, J., and Sorensen, P. (2002) Supporting the Use of Web-based

Materials by PGCE Secondary Science Students. Retrieved March $3^{\text {rd }} 2003$ from http://brs.leeds.ac.uk/cgibin/brs_engine?* $\mathrm{ID}=13 \& * \mathrm{DB}=\mathrm{BEID} \& * \mathrm{DD}=$ Document: $\%$ $201 \% 3 \mathrm{CBR} \% 3 \mathrm{E} \& * \mathrm{TH}=\mathrm{BEIT} \& * \mathrm{TX}=\mathrm{Y} \&$ $* \mathrm{HI}=\mathrm{N} \& * \mathrm{UZ}=000002192[\mathrm{DOCN}] \& * \mathrm{QX}$ $=\% 7 \mathrm{E} \% 7 \mathrm{E}$ TWIDLE $\% 5 \mathrm{BAUTH} \% 5 \mathrm{D}$.

Formatted: Default Paragraph Font 
1

2

3

4

5

6

7

8

9

10

11

12

13

14

15

16

17

18

19

20

21

22

23

24

25

26

27

28

29

30

31

32

33

34

35

36

37

38

39

40

41

42

43

44

45

46

47

48

49

50

51

52

53

54

55

56

57

58

59

60
Vradisas, C. and McIsaac, M. S. (2001) Integrating Technology in Teaching and Teacher Education:

Implications for Policy and Curriculum Reform. Educational Media International 38(2-3), 127-132

Watson, D.M. (2001). Pedagogy before technology: Rethinking the Relationship between ICT and Teaching.

Education and Information Technologies, 6(4), 251-266.

White, R.T. (2000). The Knowledge Integration Environment: a commentary on research. International

\footnotetext{
Journal of Science Education, 22(8), 873-880.
}

Formatted: Font: (Default) Times New Roman, 12 pt, Not Bold, Complex Script Font: Times New Roman, $12 \mathrm{pt}$

URL: http://mc.manuscriptcentral.com/tsed Email: editor_ijse@hotmail.co.uk 
1

2

3

4

5

6

7

8

9

10

11

12

13

14

15

16

17

18

19

20

21

22

23

24

25

26

27

28

29

30

31

32

33

34

35

36

37

38

39

40

41

42

43

44

45

46

47

48

49

50

51

52

53

54

55

56

57

58

59

60

Table 1: Details of numbers involved in the phases of the research

\begin{tabular}{llll}
\hline Phase & Questionnaires & Focus Groups & Case Studies \\
\hline Year 1 & $\mathrm{n}=15$ (pilot) & $\begin{array}{l}\text { 5 groups at each HEI } \\
\text { centres plus } \\
\text { 12 student teachers } \\
\text { discussing } \\
\text { questionnaires }\end{array}$ & $\begin{array}{l}11 \text { (student } \\
\text { teachers only) }\end{array}$ \\
& & & 12 (student \\
& & teachers \\
& & only) \\
\hline Year 2 & $\mathrm{n}=151$ & $\begin{array}{l}5 \text { (student } \\
\text { teachers and } \\
\text { their } \\
\end{array}$ \\
& & mentors) \\
\hline Year 3 & $\mathrm{n}=153$ & \\
\hline Year 4 & $\mathrm{n}=166$ & \\
& & &
\end{tabular}

URL: http://mc.manuscriptcentral.com/tsed Email: editor_ijse@hotmail.co.uk 
Table 2: Comparison statistics for questionnaire items used over years 1 - 4

\begin{tabular}{|c|c|c|c|c|c|c|c|c|c|}
\hline \multicolumn{2}{|c|}{ Code $\rightarrow$} & \multicolumn{2}{|c|}{1} & \multicolumn{2}{|c|}{2} & \multicolumn{2}{|c|}{3} & \multicolumn{2}{|c|}{4} \\
\hline Question & Year & Count & $\%$ & Count & $\%$ & Count & $\%$ & Count & $\%$ \\
\hline \multirow[t]{4}{*}{$1 \mathrm{a}$} & 1 & 4 & $3.1 \%$ & 83 & $64.8 \%$ & 41 & $32.0 \%$ & & \\
\hline & 2 & 1 & $.7 \%$ & 89 & $59.3 \%$ & 60 & $40.0 \%$ & & \\
\hline & 3 & 1 & $.7 \%$ & 69 & $45.1 \%$ & 83 & $54.2 \%$ & & \\
\hline & 4 & 1 & $.6 \%$ & 91 & $55.2 \%$ & 73 & $44.2 \%$ & & \\
\hline \multirow[t]{4}{*}{$1 b$} & 1 & 10 & $7.8 \%$ & 87 & $68.0 \%$ & 31 & $24.2 \%$ & & \\
\hline & 2 & 6 & $4.0 \%$ & 100 & $66.7 \%$ & 44 & $29.3 \%$ & & \\
\hline & 3 & 6 & $3.9 \%$ & 85 & $55.9 \%$ & 61 & $40.1 \%$ & & \\
\hline & 4 & 5 & $3.0 \%$ & 109 & $66.1 \%$ & 51 & $30.9 \%$ & & \\
\hline \multirow[t]{4}{*}{2} & 1 & 105 & $82.7 \%$ & 22 & $17.3 \%$ & & & & \\
\hline & 2 & 133 & $88.1 \%$ & 18 & $11.9 \%$ & & & & \\
\hline & 3 & 122 & $80.8 \%$ & 28 & $18.5 \%$ & 1 & $.7 \%$ & & \\
\hline & 4 & 146 & $88.0 \%$ & 20 & $12.0 \%$ & & & & \\
\hline \multirow[t]{4}{*}{$3 a$} & 1 & 8 & $6.8 \%$ & 20 & $16.9 \%$ & 41 & $34.7 \%$ & 49 & $41.5 \%$ \\
\hline & 2 & 2 & $1.4 \%$ & 9 & $6.5 \%$ & 51 & $37.0 \%$ & 76 & $55.1 \%$ \\
\hline & 3 & 6 & $4.2 \%$ & 8 & $5.6 \%$ & 39 & $27.1 \%$ & 91 & $63.2 \%$ \\
\hline & 4 & 8 & $4.8 \%$ & 2 & $1.2 \%$ & 43 & $25.9 \%$ & 113 & $68.1 \%$ \\
\hline \multirow[t]{4}{*}{$3 b$} & 1 & 27 & $23.3 \%$ & 34 & $29.3 \%$ & 40 & $34.5 \%$ & 15 & $12.9 \%$ \\
\hline & 2 & 16 & $11.7 \%$ & 30 & $21.9 \%$ & 57 & $41.6 \%$ & 34 & $24.8 \%$ \\
\hline & 3 & 15 & $10.6 \%$ & 22 & $15.6 \%$ & 57 & $40.4 \%$ & 47 & $33.3 \%$ \\
\hline & 4 & 22 & $13.3 \%$ & 27 & $16.4 \%$ & 72 & $43.6 \%$ & 44 & $26.7 \%$ \\
\hline \multirow[t]{4}{*}{$3 c$} & 1 & 45 & $38.5 \%$ & 36 & $30.8 \%$ & 27 & $23.1 \%$ & 9 & $7.7 \%$ \\
\hline & 2 & 30 & $22.7 \%$ & 43 & $32.6 \%$ & 38 & $28.8 \%$ & 21 & $15.9 \%$ \\
\hline & 3 & 19 & $13.3 \%$ & 37 & $25.9 \%$ & 56 & $39.2 \%$ & 31 & $21.7 \%$ \\
\hline & 4 & 32 & $19.5 \%$ & 42 & $25.6 \%$ & 64 & $39.0 \%$ & 26 & $15.9 \%$ \\
\hline \multirow[t]{4}{*}{$3 d$} & 1 & 9 & $7.7 \%$ & 7 & $6.0 \%$ & 34 & $29.1 \%$ & 67 & $57.3 \%$ \\
\hline & 2 & 3 & $2.2 \%$ & 4 & $2.9 \%$ & 34 & $24.6 \%$ & 97 & $70.3 \%$ \\
\hline & 3 & 4 & $2.8 \%$ & 4 & $2.8 \%$ & 28 & $19.6 \%$ & 107 & $74.8 \%$ \\
\hline & 4 & 8 & $4.8 \%$ & 4 & $2.4 \%$ & 31 & $18.7 \%$ & 123 & $74.1 \%$ \\
\hline $4 a$ & 1 & 30 & $23.4 \%$ & 27 & $21.1 \%$ & 50 & $39.1 \%$ & 21 & $16.4 \%$ \\
\hline
\end{tabular}

URL: http://mc.manuscriptcentral.com/tsed Email: editor_ijse@hotmail.co.uk 


\begin{tabular}{|c|c|c|c|c|c|c|c|c|c|}
\hline & 2 & 11 & $7.3 \%$ & 21 & $14.0 \%$ & 74 & $49.3 \%$ & 44 & $29.3 \%$ \\
\hline & 3 & 2 & $1.3 \%$ & 14 & $9.3 \%$ & 68 & $45.3 \%$ & 66 & $44.0 \%$ \\
\hline & 4 & 5 & $3.0 \%$ & 21 & $12.7 \%$ & 68 & $41.0 \%$ & 72 & $43.4 \%$ \\
\hline \multirow[t]{4}{*}{$4 \mathrm{~b}$} & 1 & 54 & $42.2 \%$ & 44 & $34.4 \%$ & 27 & $21.1 \%$ & 3 & $2.3 \%$ \\
\hline & 2 & 31 & $20.9 \%$ & 53 & $35.8 \%$ & 49 & $33.1 \%$ & 15 & $10.1 \%$ \\
\hline & 3 & 17 & $11.4 \%$ & 41 & $27.5 \%$ & 69 & $46.3 \%$ & 22 & $14.8 \%$ \\
\hline & 4 & 22 & $13.4 \%$ & 43 & $26.2 \%$ & 81 & $49.4 \%$ & 18 & $11.0 \%$ \\
\hline \multirow[t]{4}{*}{$4 c$} & 1 & 70 & $54.7 \%$ & 35 & $27.3 \%$ & 21 & $16.4 \%$ & 2 & $1.6 \%$ \\
\hline & 2 & 39 & $27.1 \%$ & 58 & $40.3 \%$ & 38 & $26.4 \%$ & 9 & $6.3 \%$ \\
\hline & 3 & 19 & $12.7 \%$ & 48 & $32.0 \%$ & 65 & $43.3 \%$ & 18 & $12.0 \%$ \\
\hline & 4 & 30 & $18.4 \%$ & 51 & $31.3 \%$ & 65 & $39.9 \%$ & 17 & $10.4 \%$ \\
\hline \multirow[t]{4}{*}{$4 d$} & 1 & 43 & $33.6 \%$ & 22 & $17.2 \%$ & 41 & $32.0 \%$ & 22 & $17.2 \%$ \\
\hline & 2 & 22 & $14.6 \%$ & 38 & $25.2 \%$ & 50 & $33.1 \%$ & 41 & $27.2 \%$ \\
\hline & 3 & 14 & $9.3 \%$ & 40 & $26.7 \%$ & 50 & $33.3 \%$ & 46 & $30.7 \%$ \\
\hline & 4 & 12 & $7.3 \%$ & 40 & $24.4 \%$ & 68 & $41.5 \%$ & 44 & $26.8 \%$ \\
\hline \multirow[t]{4}{*}{5} & 1 & 19 & $14.8 \%$ & 45 & $35.2 \%$ & 49 & $38.3 \%$ & 15 & $11.7 \%$ \\
\hline & 2 & 18 & $11.9 \%$ & 66 & $43.7 \%$ & 58 & $38.4 \%$ & 9 & $6.0 \%$ \\
\hline & 3 & 8 & $5.3 \%$ & 60 & $39.5 \%$ & 65 & $42.8 \%$ & 19 & $12.5 \%$ \\
\hline & 4 & 13 & $7.8 \%$ & 64 & $38.6 \%$ & 74 & $44.6 \%$ & 15 & $9.0 \%$ \\
\hline
\end{tabular}


Table 3: Kruskal Wallis significance results for questions used over years $1-4$

\begin{tabular}{lccc}
\hline Question & Chi-Square & df & \multicolumn{2}{c}{ Asymp. Sig. } \\
\hline $1 \mathrm{a}$ & 14.427 & 3 & .002 \\
\hline $1 \mathrm{~b}$ & 9.075 & 3 & .028 \\
\hline 2 & 4.974 & 3 & .174 \\
\hline $3 \mathrm{a}$ & 26.695 & 3 & .000 \\
\hline $3 \mathrm{~b}$ & & & .000 \\
\hline $3 \mathrm{c}$ & 25.996 & 3 & .000 \\
\hline $3 \mathrm{~d}$ & 32.679 & 3 & .005 \\
\hline $4 \mathrm{a}$ & 12.918 & 3 & .000 \\
\hline $4 \mathrm{~b}$ & 61.510 & 3 & .000 \\
\hline $4 \mathrm{c}$ & 65.140 & 3 & .000 \\
\hline $4 \mathrm{~d}$ & 77.582 & 3 & .000 \\
\hline 5 & 21.396 & 3 & \\
\hline & 6.870 & 3 & \\
\hline
\end{tabular}

30

31

32

33

34

35

36

37

38

39

40

41

42

43

44

45

46

47

48

49

50

51

52

53

54

55

56

57

58

59

60

URL: http://mc.manuscriptcentral.com/tsed Email: editor_ijse@hotmail.co.uk 
1

2

3

4

5

7

7
8

9

10

11
12

12

13
14

15

16

17

18

19

20

21

22

2$$
2
$$

25
26

2

27
28

29

30

3

32

33
34

3

35

3
3
3

37

3

3

39

40

41

42

43

44

45

46

47

48

49

50

51

52

53

54

55

56

57

58

59

60

Table 4: Comparison statistics for questionnaire items used over years $2-4$

\begin{tabular}{|c|c|c|c|c|c|c|c|c|c|}
\hline \multicolumn{2}{|c|}{ Code $\rightarrow$} & \multicolumn{2}{|c|}{1} & \multicolumn{2}{|c|}{2} & \multicolumn{2}{|c|}{3} & \multicolumn{2}{|c|}{4} \\
\hline Question & Year & Count & $\%$ & Count & $\%$ & Count & $\%$ & Count & $\%$ \\
\hline \multirow[t]{3}{*}{6} & 2 & & & 27 & $18.0 \%$ & 59 & $39.3 \%$ & 56 & $37.3 \%$ \\
\hline & 3 & & & 8 & $5.4 \%$ & 54 & $36.5 \%$ & 67 & $45.3 \%$ \\
\hline & 4 & & & 15 & $9.1 \%$ & 55 & $33.3 \%$ & 72 & $43.6 \%$ \\
\hline \multirow[t]{3}{*}{$7 a$} & 2 & & & 136 & $90.1 \%$ & 15 & $9.9 \%$ & & \\
\hline & 3 & & & 140 & $92.1 \%$ & 12 & $7.9 \%$ & & \\
\hline & 4 & & & 148 & $89.2 \%$ & 18 & $10.8 \%$ & & \\
\hline \multirow[t]{3}{*}{$7 \mathrm{~b} 1$} & 2 & 96 & $63.6 \%$ & 55 & $36.4 \%$ & & & & \\
\hline & 3 & 80 & $52.3 \%$ & 73 & $47.7 \%$ & & & & \\
\hline & 4 & 72 & $43.4 \%$ & 94 & $56.6 \%$ & & & & \\
\hline \multirow[t]{3}{*}{$7 \mathrm{~b} 2$} & 2 & 34 & $22.5 \%$ & 117 & $77.5 \%$ & & & & \\
\hline & 3 & 33 & $21.6 \%$ & 120 & $78.4 \%$ & & & & \\
\hline & 4 & 47 & $28.3 \%$ & 119 & $71.7 \%$ & & & & \\
\hline \multirow[t]{3}{*}{$7 \mathrm{~b} 3$} & 2 & 43 & $28.5 \%$ & 108 & $71.5 \%$ & 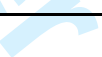 & & & \\
\hline & 3 & 44 & $28.8 \%$ & 109 & $71.2 \%$ & & & & \\
\hline & 4 & 63 & $38.0 \%$ & 103 & $62.0 \%$ & & & & \\
\hline \multirow[t]{3}{*}{$7 \mathrm{c}$} & 2 & & & 2 & $1.4 \%$ & 3 & $2.2 \%$ & 56 & $40.6 \%$ \\
\hline & 3 & & & & & 4 & $2.8 \%$ & 42 & $29.4 \%$ \\
\hline & 4 & & & 1 & $.7 \%$ & 4 & $2.7 \%$ & 51 & $34.2 \%$ \\
\hline \multirow[t]{3}{*}{10} & 2 & & & & & 1 & $.7 \%$ & 22 & $15.3 \%$ \\
\hline & 3 & & & & & & & 22 & $14.6 \%$ \\
\hline & 4 & & & & & & & 19 & $11.6 \%$ \\
\hline \multirow[t]{3}{*}{12} & 2 & & & & & 3 & $2.1 \%$ & 75 & $52.1 \%$ \\
\hline & 3 & & & & & 1 & $.7 \%$ & 75 & $51.0 \%$ \\
\hline & 4 & & & 1 & $.6 \%$ & 3 & $1.8 \%$ & 81 & $49.1 \%$ \\
\hline
\end{tabular}

URL: http://mc.manuscriptcentral.com/tsed Email: editor_ijse@hotmail.co.uk 
Table 5: Kruskal Wallis significance results for questions used over years $2-4$

\begin{tabular}{lrrr}
\hline Question & Chi-Square & df & Asymp. Sig. \\
\hline 6 & 15.628 & 2 & .000 \\
\hline $7 \mathrm{a}$ & .823 & 2 & .663 \\
\hline $7 \mathrm{~b} 1$ & 12.942 & 2 & .002 \\
\hline $7 \mathrm{~b} 2$ & 2.332 & 2 & .312 \\
\hline $7 \mathrm{~b} 3$ & 4.298 & 2 & .117 \\
\hline $7 \mathrm{c}$ & 4.216 & 2 & .122 \\
\hline 10 & 1.342 & 2 & .511 \\
\hline 12 & .312 & 2 & .855 \\
\hline
\end{tabular}




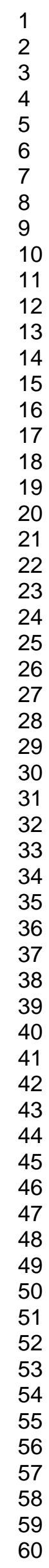

21

23

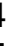


Table 6: Barriers to use of the Internet

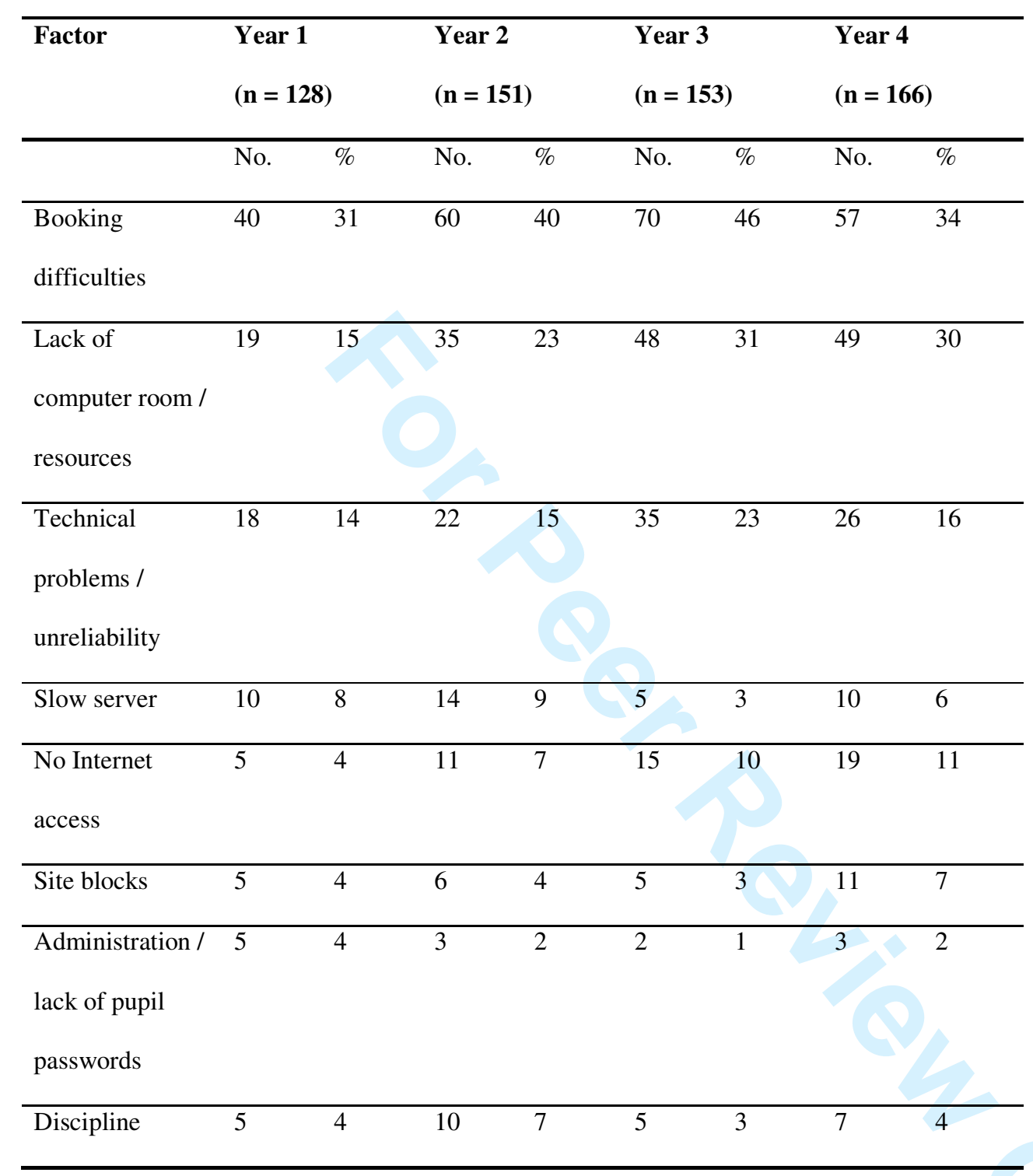

Formatted: Left 
Appendix 1: Areas examined in the questionnaire relevant to the research

1a Competence in using search engines

$\underline{1 \mathrm{~b} \text { Competence in creating search phrases }}$

2. Home Access

3a Regularity of use of the Internet at home for background research for lesson preparation

$3 \mathrm{~b}$ Regularity of use of the Internet at home to prepare self-study packages for pupils

$\underline{3 c}$ Regularity of use of the Internet at home to prepare interactive study packages for pupils $\underline{3 d}$ Regularity of use of the Internet at home for students' own interest

4a Regularity of use of the Internet at school for background research for lesson preparation $4 \mathrm{~b}$ Regularity of use of the Internet at school to prepare self-study packages for pupils $4 \mathrm{c}$ Regularity of use of the Internet at school to prepare interactive study packages for pupils $4 \mathrm{~d}$ Regularity of use of the Internet at school for students' own interest

5 Use of the Internet by other science teachers with classes while on teaching practice

6 Use of the Internet by other science teachers in planning lessons while on teaching practice

Formatted: Left, Indent: Before: 0 pt 7 a Use of the Internet during lessons $7 \mathrm{~b}$ Types of use of the Internet during lessons $7 \mathrm{c}$ Success in using the Internet during lessons 8 Barriers to use of the Internet

9 Types of search engines used 10 Rate of success in finding information on the Internet

11 Sites used for finding information

12 Potential of the Internet as a tool for teaching 13 Areas for development that would increase use of the Internet 